ENGINEERING ETHICS 
This page intentionally left blank 
DEBORAH G. JOHNSON

\title{
ENGINEERING ETHICS
}

Contemporary and Enduring Debates

\author{
Yale \\ UNIVERSITY \\ PRESS
}

NEW HAVEN AND LONDON 
Published with assistance from the Mary Cady Tew Memorial Fund.

Copyright (C) 2020 by Deborah G. Johnson.

All rights reserved. This book may not be reproduced, in whole or in part, including illustrations, in any form (beyond that copying permitted by Sections 107 and 108 of the US Copyright Law and except by reviewers for the public press), without written permission from the publishers.

Yale University Press books may be purchased in quantity for educational, business, or promotional use. For information, please e-mail sales.press@yale.edu (US office) or sales@yaleup.co.uk (UK office).

Set in New Aster type by IDS Infotech Ltd., Chandigarh, India. Printed in the United States of America.

Library of Congress Control Number: 2019948567

ISBN 978-0-300-20924-2 (pbk. : alk. paper)

A catalogue record for this book is available from the British Library.

This paper meets the requirements of ANSI/NISO Z39.48-1992 (Permanence of Paper). 